of anesthesiology over the course of a year". You can view the full syllabus at http://theanswerpage.com/ anesthesiology/news.html\#Syllabus. Finally, there is also a search feature where one can search through past questions for certain key words.

I was most impressed with this marvelous educational initiative. Highly recommended.

D. John Doyle MD PHD FRCPC

Toronto, Ontario

\section{Truth, Lies, and the Internet}
"The truth shall make you free, but first it shall make you angry." - Anon.
"All great truths begin as blasphemies." - George Bernard Shaw
"It is hard to believe that a man is telling the truth when you know that you would lie if you were in his place." - H.L. Mencken
"As scarce as truth is, the supply has always been in excess of the demand." - Josh Billings

One of the unexpected advantages of the explosion of information on the Internet is the realization by most people (or at the least the more sophisticated individuals among us) that one can't always believe everything one reads. While political radicals have been sending this message about the print and broadcast media for years (consider, for instance, the writings of Noam Chomsky [http://www.zmag.org/chomsky]), the awareness that the Internet runs rampant with spoofs, false virus scares, urban legends, and outright lies has sensitized individuals to the need for critical appraisal of whatever passes before their eyes.

The fact that a message can circulate from its point of origin to all corners of the globe in minutes is both one of the Internet's greatest strengths and one of its greatest weaknesses. Recently, this duality was convincingly demonstrated by the Kurt Vonnegut E-mail hoax, where a University graduation speech purportedly given at the Massachusetts Institute of Technology by Mr. Vonnegut, a well-known writer, was in fact a Chicago Tribune piece written by Mary Schmich, until recently a little-known columnist. http://chicagotribune.com/news/columnists/schmi ch 0,1122, SAV-9706010178,00.html

The alleged speech, which began by advising graduates to wear sunscreen, charmed countless thousands of readers and was even cast into a popular song (Sun Screen Song. Something For Everybody. Baz Luhrmann ). The message spread via E-mail from friend to friend, co-worker to co-worker, around the world. Even Vonnegut's wife received the message and believed it to be genuine. Few readers had reason to doubt the authenticity of the material until the hoax was exposed. Details of the story are available on the Internet [http://urbanlegends.miningco.com/ library/weekly/aa081097.htm].

While this hoax was a relatively harmless occurrence, one can easily imagine embarrassing or even libelous consequences from false information on the Internet. For instance, veteran American newsman Pierre Salinger's widely reported missile theory for the downing of flight TWA 800, based primarily on Internet sources, turned out to be completely without foundation [http://infomanage.com/secrets/twa800/ govsal800.htm].

On the other hand, the Internet has sometimes served as an important source of information before being disseminated by conventional media. For instance, information about the Monica Lewinsky affair took place first on the Internet, initially through the "scoop" of Matt Drudge, (http://www.drudgereport.com) which made it news before it reached the newspapers, then through the publication of the Starr Report on government websites, which recorded six million hits within twenty-four hours. (Incidentally, a nice parody of the Drudge Report is available at http://www.drudge.com).

The Internet is also one of the most powerful agents of freedom. For example, it played an important role in providing accurate information to the West during the brief Soviet military coup when Gorbachev was in power (mostly via E-mail from Russian scientists sent to colleagues around the world). Indeed, it is no wonder that most governments with totalitarian tendencies fear the Internet.

These issues not withstanding, Internet misinformation remains a problem. Serious misuses of the Internet include stock manipulation, false advertising, as well as using "chat lines" under an assumed identify with a view to corrupting children. Information on these and other Internet crimes are available at the addresses below:

http://ciac.llnl.gov/ciac/CIACHoaxes.html

http://www.urbanlegends.com/

The Internet has been especially useful to individuals wishing to promote unproven clinical treatments. An Internet search using the term "alternative medicine" will produce hundreds upon hundreds of hits covering chiropractic, homeopathy, iridology, reflexology and many other controversial therapies. Many of these sites offer useless or even dangerous products for sale. Many sites also have a legal disclaimer such as the following 
(from http://www.healthfromnature.com/alternative. html): "The research contained on this site is general in nature and has been compiled, reviewed and corrected to the best of the authors ability. It is presented for educational purposes. It is your personal responsibility to determine the validity of any and all information presented. Each nutritional supplement product is NOT a drug and NOT represented as having any medicinal value." Presumably, the authors feel that this warning is sufficient to ward off any legal trouble should any misinformation provided lead to harm.

Readers interested in more information on unorthodox and unconventional clinical therapies can obtain a comprehensive critique of these methods at http://www.quackwatch.com and http://www. hcrc.org. The latter resource contains a rich selection of links to anti-quackery sites.

The power of the Internet is like a two-edged sword. It can deliver misinformation and uncorroborated opinion with equal ease. The thoughtful and the thoughtless co-exist side by side in cyberspace.

D. John Doyle MD PHD FRCPC

Toronto, Ontario

\section{ROMs and Anesthesia Machines}

At a recent conference I was given two free CD ROMs by the kind man at the Datex-Ohmeda booth. The first, bearing the pedestrian title "AS/3 Anesthesia Delivery Unit", uses Macromedia Director to provide an interactive multimedia presentation about their anesthesia machine. Although the CD ROM is very nicely done, it is still basically just a fancy marketing brochure, being well illustrated, and well narrated, but very short on technical detail. One advantage of providing marketing information in this way is that the per copy cost of producing a CD ROM can be much less than producing complex multicolour brochures that we associate with the marketing of high-technology medical products. Another advantage is that CD ROMs usually takes up less storage space. Incidentally, Datex-Ohmeda also use CD ROM technology for distributing all the technical manuals for their products. This means that it is easy to search electronically for obscure information and it even would be possible to provide video clips showing how correct disassembly and reassembly should be carried out.

The second CD ROM I received is much, much more than a marketing "throw away" and is entitled "The Evolution of the Anesthesia Machine". You will definitely want keep your copy of this CD ROM. This instructional product was conceived and developed by Drs. Ortega and Arkoff, both practitioners at Boston University at the time. It is a marvelous multimedia historical survey of the evolution of the technology used in our profession, and is again produced using Macromedia Director. This project was carried out in collaboration with the Wood Library Museum of the American Society of Anesthesiologists and was awarded first prize for being the outstanding scientific and educational exhibit at ASA annual meeting in 1998. Next month I will provide a complete review of this outstanding product. Meanwhile, if the history of our profession interests you, do try to get your own copy.

\author{
D. John Doyle MD PHD FRCPC \\ Toronto, Ontario
}

